\title{
STUDIES ON THE DRUG RESISTANCE OF STAPHYLOCOCCI AND ESCHERICHIA COLI AGAINST ANTIBIOTICS. II
}

\author{
GENERAL TENDENGY OF RESISTANT STRAINS
}

\author{
Hrrokazu Otaya, Saburo Okamoto, Emiko Inoue*, \\ Yasuaki Adachi, Suguru Machinara and Mikio Yoshimura \\ Shionogi \& Co., Ltd., Osaka, Japan and \\ Gracia Hospital, Osaka, Japan*
}

(Received for publication May 14, 1970)

\begin{abstract}
To evaluate the changes of the susceptibilities of Staphylococcus aureus and Escherichia coli clinical isolates over a four-year period from 1965 through 1968 , we have conducted a series of studies. Results from these studies were used to assess the changes of bacterial sensitivities within groups of bacteria classified according to minimal inhibitory concentrations (MIC) values or having high sensitivity, intermediate sensitivity, or low sensitivity. We were able to compare changes in antibiotic activities more accurately by this technique than by our previous method of comparison of the averages of the MIC values only.
\end{abstract}

For more than a decade, several investigators have performed studies on sensitivities of various pathogenic bacteria to antibiotics and chemotherapeutic agents used in Japan. Results of several long-term studies, including the first extensive investigation by the National Hospital Research Group on pathogenic staphylococci, headed by KoSAKAI ${ }^{1)}$, are published. The work by the Resistant Staphylococci Research Group, headed by ICHIKAWA ${ }^{2)}$, has continued since 1961. Each of these many studies has had a different purpose of its own; therefore, as one manufacturer of antibiotics, we have not been fully satisfied with the results reported. For example, the data shown in Fig. 1 summarizes the results on the resistance of staphylococci to erythromycin as reported in Japanese scientic journals ${ }^{3)}$ between 1955 and 1965. The general trend of a gradual increases in the rate of resistant strains is evident; however, there is a marked fluctuation among individual tests caused by differences in methods of sampling, testing, etc.

To more accurately evaluate the trends of bacterial resistance to antibiotics, we have conducted a series of studies since 1964 by a different procedure that is described below. Bacterial isolates have been collected twice yearly (Nov. May and June Oct.) from central clinical laboratories throughout Japan. Nine studies have been completed so far to October 1969. Because data from the first study (Nov. May 1964) were not obtained with uniform methods or drugs, our present report includes results obtained on staphylococcal and Escherichia coli isolates from the eight subsequent studies. 
Fig. 1. Erythromycin-resistant staphylococci reported in journals between $1955 \sim 1966$.

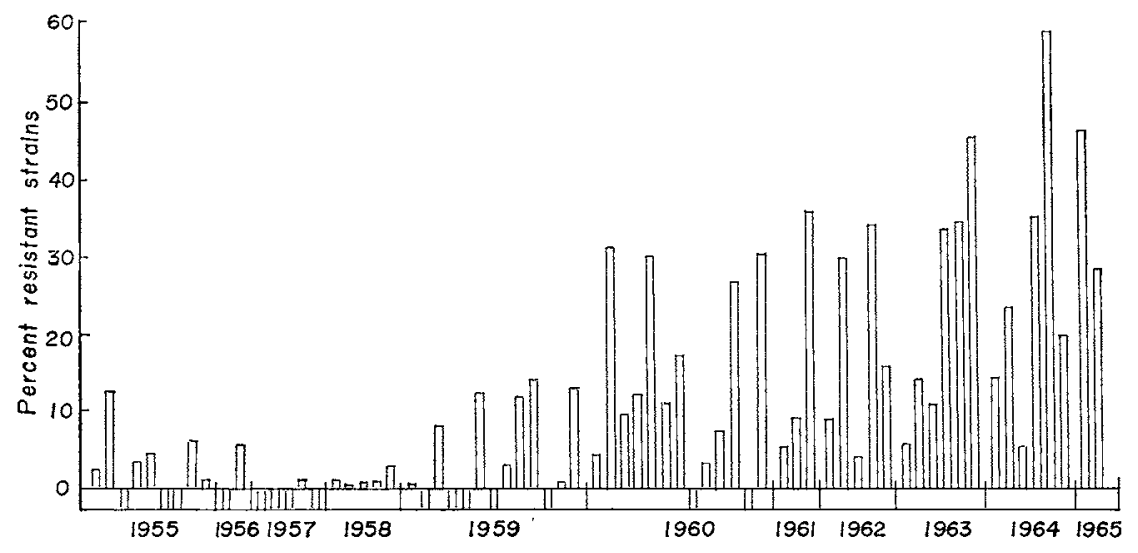

One block in the figure is related to one paper. The height of the blocks on the zero line shows percentage of resistant strains reported in the papers cited. The blocks extending below the zero line, without regard to its length, means no resistant strain.

\section{Design of Investigation}

1. Objective

Our objective was to investigate the annual trends of bacterial resistance to antibiotics and sulfonamides frequently used in hospitals.

2. Methods

(1) Bacterial isolates and hospitals were selected by a statistical sampling method.

(2) Bacterial isolates were sampled in the central clinical laboratories or other equivalent laboratories of hospitals.

(3) Testing method

1) Identification of isolate.

2) Isolated strains were propagated in a modified MULLER-Hinton's broth medium $\left(37^{\circ} \mathrm{C}, 18\right.$ hours).

3) A loopful from each culture was suspended in $5 \mathrm{ml}$ of saline with a $1 \mathrm{~mm}$ standard platinum loop.

4) Culture Media: Modified MulleR-Hinton's medium was mainly used except for the sulfanimide testing E. coli isolates where SAUTon medium was employed.

Drug-sensitivity tests were performed with the two-fold agar-dilution method with the same media.

$1 \mathrm{~mm}$ platinum loop. Agar streak method. (about $10^{4} \mathrm{cells}, 37^{\circ} \mathrm{C}, 18$ hours) Muller-Hinton Medium (Modified)

$\begin{array}{lclc}\text { Beef Heart Infusion } & 200.0 \mathrm{ml} & \text { L-Cystine } & 0.05 \mathrm{~g} \\ \text { Casamino Acids } & 16.5 \mathrm{~g} & \text { Biotin } & 5.0 \mathrm{\mu g} \\ \text { Starch } & 1.5 \mathrm{~g} & \text { Agar } & 15.0 \mathrm{~g} \\ \text { Glucose } & 2.0 \mathrm{~g} & \text { Aq. Dest } & 1,000.0 \mathrm{~g} \\ \text { L-Tryptophan } & 0.05 \mathrm{~g} & & (\mathrm{pH} 7.4 \pm 0.1)\end{array}$

Inoculum About $3 \sim 4 \times 16^{6}$ cells, $37^{\circ} \mathrm{C}, 18$ hours.

Sauton Medium (Modified) Kruger-thimer

$\begin{array}{lllr}\text { Asparagine } & 4.0 \mathrm{~g} & \text { Ferric ammonium citrate } & 0.05 \mathrm{~g} \\ \mathrm{KH}_{2} \mathrm{PO}_{4} & 0.5 \mathrm{~g} & \text { Glycerol } & 20.0 \mathrm{ml} \\ \text { Citric Acid } & 2.0 \mathrm{~g} & \text { Aq. Dest } & 1,000.0 \mathrm{ml} \\ \mathrm{MgSO}_{4} \cdot 7 \mathrm{H}_{2} \mathrm{O} & 0.5 \mathrm{~g} & & (\mathrm{pH} 7.0)\end{array}$


Fig. 2. Result of tests on control strains.
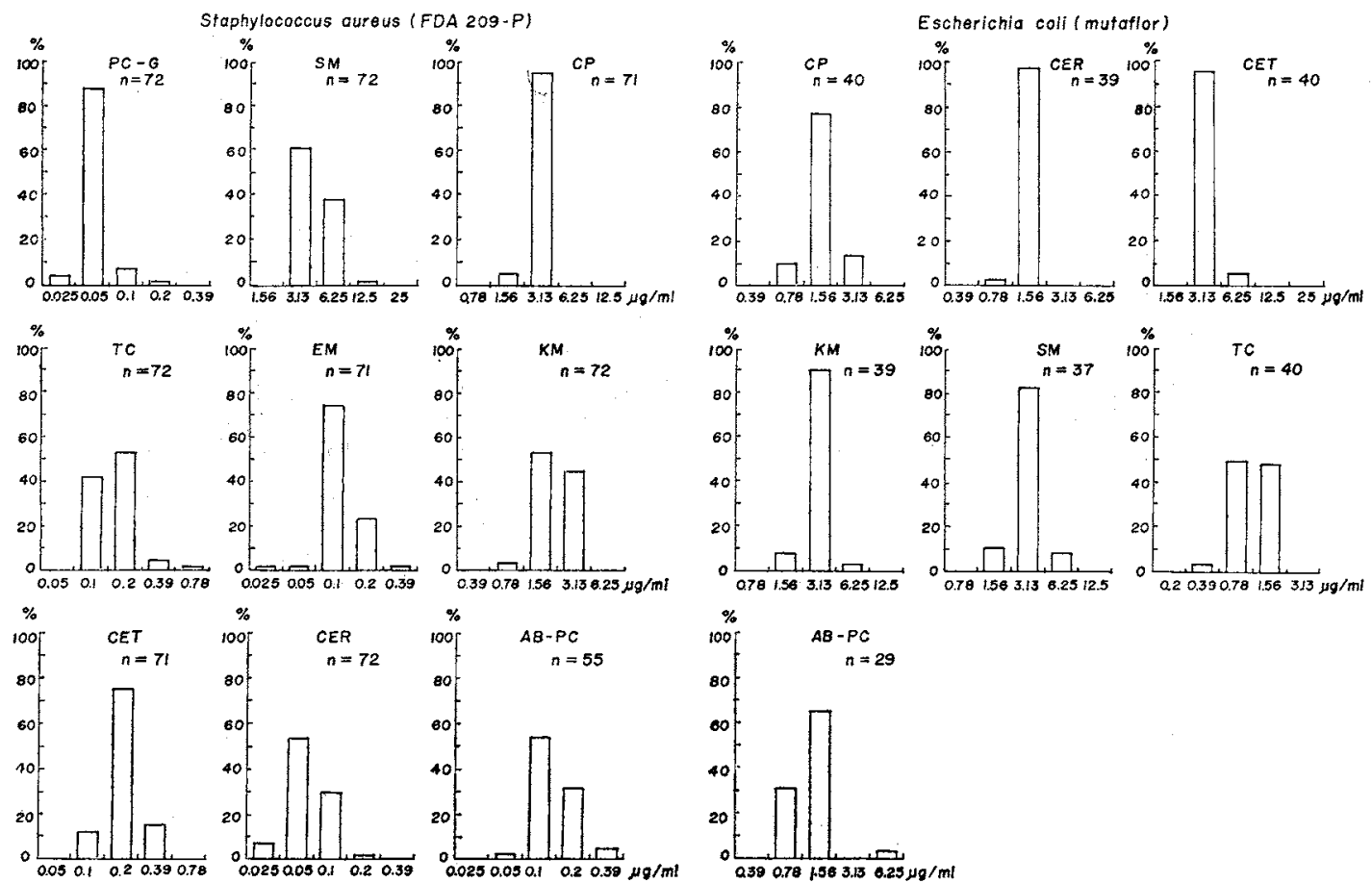

5) For the control, standard strains $S$, aureus FDA 209-P and E. coli Mutaflor $\left(K_{R U ̈ G E R}\right)^{4)}$ were used. The results with these strains are shown in Fig. 2.

3. Chemotherapeutic agents tested

S. aureus:

Erythromycin (EM), Penicillin G (PC-G), Streptomycin (SM),

Chloramphenicol (CP), Tetracycline (TC), Kanamycin (KM),

Gephalothin (CET), Cephaloridine (GER), Sulfisomezole (SIZ).

Aminobenzyl-penicillin (AB-PC)

E. coli :

CP, TC, SM, KM, CET, CER, SIZ, AB-PC

4. Period of study: June 1965 May 1969

5. Items for analysis

(1) Results of sampling

(2) Changes: (a) General tendency, (b) Multiple drug resistance

(3) Grouping by districts (7)

(4) Grouping by the size of hospitals (expressed in number of beds)

(5) Grouping by inpatients and outpatients

(6) Grouping by the age

(7) Grouping by the sources of strains

\section{Sampling}

Hospitals from which bacterial isolates were collected: Among the general 
hospitals equipped with central clinical laboratories, $10 \%$ of the larger hospitals were selected in each prefecture.

\section{Results of sampling}

1. Districts, sampling hospitals and number of strains (Tables 1,2 and 3).

2. Correlation analysis of the results of sampling (Table 4).

The correlation analysis of the factors involved have made possible the assumption of the drug sensitivities of the isolates submitted to central clinical laboratories of the hospitals in Japan.

Table 1 .

\begin{tabular}{|c|c|c|c|c|c|c|c|}
\hline \multirow{2}{*}{\multicolumn{2}{|c|}{ District }} & \multirow{2}{*}{$\begin{array}{l}\text { Population } \\
\qquad(000)\end{array}$} & \multirow{2}{*}{$\begin{array}{l}\text { Hospitals } \\
\text { No. }\end{array}$} & \multirow{2}{*}{$\begin{array}{l}\text { Sampling } \\
\text { hospitals } \\
\text { No. }\end{array}$} & \multicolumn{3}{|c|}{ No. of strains } \\
\hline & & & & & $\begin{array}{l}\text { S. } \\
\text { aureus }\end{array}$ & E. coli & Total \\
\hline I & Chiba, Tokyo, Kanagawa & 18,710 & 568 & 60 & 1,205 & 753 & 1,958 \\
\hline III & $\begin{array}{l}\text { Kyoto, Shiga, Osaka, Hyogo, } \\
\text { Nara, Wakayama }\end{array}$ & 16,498 & 594 & 62 & 776 & 489 & 1,265 \\
\hline III & $\begin{array}{l}\text { Hokkaido, Aomori, Iwate, Miyagi, } \\
\text { Akita, Yamagata, Fukushima }\end{array}$ & 14,751 & 340 & 50 & 512 & 257 & 769 \\
\hline N & Gifu, Shizuoka, Aichi, Mie & 11,433 & 274 & 45 & 622 & 320 & 942 \\
\hline $\mathrm{V}$ & $\begin{array}{l}\text { Tottori, Shimane, Okayama, } \\
\text { Hiroshima, Yamaguchi, Tokushima, } \\
\text { Kagawa, Ehime, Kochi }\end{array}$ & 11,188 & 324 & 27 & 322 & 169 & 491 \\
\hline V & $\begin{array}{l}\text { Fukuoka, Saga, Nagasaki, Kumamoto, } \\
\text { Oita, Miyazaki, Kagoshima }\end{array}$ & 12,770 & 246 & 37 & 415 & 298 & 713 \\
\hline VII & $\begin{array}{l}\text { Ibaragi, Tochigi, Gumma, Saitama, } \\
\text { Toyama, Nigata, Ishikawa, Fukui, } \\
\text { Yamanashi, Nagoya. }\end{array}$ & 16,639 & 293 & 64 & 622 & 410 & 1,032 \\
\hline & Total & 101,989 & 2,639 & 345 & 4,474 & 2,696 & 7,170 \\
\hline
\end{tabular}

Table 2. Numbers of Staphylococcus aureus (Coagulase positive) strains classified by years and sources. (Period: June 1965 May 1969)

\begin{tabular}{|c|c|c|c|c|c|c|c|c|c|c|}
\hline \multirow[b]{2}{*}{ Specimen } & \multicolumn{2}{|c|}{1965} & \multicolumn{2}{|c|}{1966} & \multicolumn{2}{|c|}{1967} & \multicolumn{2}{|c|}{1968} & \multicolumn{2}{|c|}{ Total } \\
\hline & $\begin{array}{l}\text { No. of } \\
\text { strains }\end{array}$ & $\%$ & $\begin{array}{l}\text { No. of } \\
\text { strains }\end{array}$ & $\%$ & $\begin{array}{l}\text { No. of } \\
\text { strains }\end{array}$ & $\%$ & $\begin{array}{l}\text { No. of } \\
\text { strains }\end{array}$ & $\%$ & $\begin{array}{l}\text { No. of } \\
\text { strains }\end{array}$ & $\%$ \\
\hline Pus & 707 & 71.2 & 671 & $71 . \overline{3}$ & 827 & 67.4 & 733 & 71.1 & 2,938 & 70.1 \\
\hline Pharyngeal mucus & 101 & 10.2 & 90 & 9.6 & 151 & 12.3 & 111 & 10.8 & 453 & 10.8 \\
\hline Sputum & 80 & 8.0 & 63 & 6.7 & 92 & 7.5 & 113 & 10.9 & 348 & 8.3 \\
\hline Urine & 58 & 5.8 & 66 & 7.0 & 89 & 7.2 & 27 & 2.6 & 240 & 5.7 \\
\hline Feces & 4 & 0.4 & 2 & 0.2 & 14 & 1.1 & 8 & 0.8 & 28 & 0.7 \\
\hline Blood & 11 & 1.1 & 12 & 1.3 & 8 & 0.7 & 7 & 0.7 & 38 & 0.9 \\
\hline Spinal fluid & 6 & 0.6 & 2 & 0.2 & 7 & 0.6 & 4 & 0.4 & 19 & 0.5 \\
\hline Punctate & 4 & 0.4 & 8 & 0.8 & 8 & 0.7 & 2 & 0.2 & 22 & 0.5 \\
\hline Ascites & 2 & 0.2 & & & & & & & 2 & \\
\hline Thoracic fluid & 7 & 0.7 & 7 & 0.7 & 5 & 0.4 & 4 & 0.4 & 23 & 0.5 \\
\hline Bile & 4 & 0.4 & 2 & 0.2 & 8 & 0.7 & 8 & 0.8 & 22 & 0.5 \\
\hline Joint fluid & 1 & 0.1 & 4 & 0.4 & 3 & 0.2 & 3 & 0.3 & 11 & 0.3 \\
\hline Washout liquid & 2 & 0.2 & 1 & 0.1 & 1 & 0.2 & & & 4 & 0.1 \\
\hline Skin piece & 3 & 0.3 & 1 & 0.1 & & & & & 4 & 0.1 \\
\hline Others & 4 & 0.4 & 13 & 1. 4 & 13 & 1.1 & 11 & 1.0 & 41 & 1.0 \\
\hline Total & 994 & 100.0 & 942 & 100.0 & 1,226 & 100.0 & 1,031 & 100.0 & 4,193 & 100.0 \\
\hline
\end{tabular}


Table 3. Numbers of Escherichia coli strains classified by years and sources. (Period: June 1965 May 1969)

\begin{tabular}{|c|c|c|c|c|c|c|c|c|c|c|}
\hline \multirow[b]{2}{*}{ Specimen } & \multicolumn{2}{|c|}{1965} & \multicolumn{2}{|c|}{1966} & \multicolumn{2}{|c|}{1967} & \multicolumn{2}{|c|}{1968} & \multicolumn{2}{|c|}{ Tota1 } \\
\hline & $\begin{array}{l}\text { No. of } \\
\text { strains }\end{array}$ & $\%$ & $\begin{array}{l}\text { No. of } \\
\text { strains }\end{array}$ & $\%$ & $\begin{array}{l}\text { No. of } \\
\text { strains }\end{array}$ & $\%$ & $\begin{array}{l}\text { No. of } \\
\text { strains }\end{array}$ & $\%$ & $\begin{array}{l}\text { No. of } \\
\text { strains }\end{array}$ & $\%$ \\
\hline Pus & 48 & $12 . \overline{1}$ & 71 & 12.8 & 92 & 11.8 & 75 & 9.2 & 286 & 11.3 \\
\hline Pharyngeal mucus & 11 & 2.8 & 5 & 0.9 & 13 & 1.7 & 13 & 1.6 & 42 & 1.7 \\
\hline Sputum & 5 & 1.2 & 6 & 1.1 & 12 & 1.5 & 22 & 2.7 & 45 & 1.8 \\
\hline Urine & 262 & 66.1 & 374 & 67.6 & 543 & 70.0 & 619 & 76.1 & 1,798 & 70.8 \\
\hline Feces & 37 & 9.3 & 67 & 12.1 & 75 & 9.7 & 46 & 5.6 & 225 & 8.9 \\
\hline Blood & 2 & 0.5 & 1 & 0.2 & 6 & 0.8 & 2 & 0.2 & 11. & 0.4 \\
\hline Spinal fluid & & & 1 & 0.2 & 1 & 0.1 & 3 & 0.4 & 5 & 0.2 \\
\hline Punctate & & & & & & & 1 & 0.1 & 1 & \\
\hline Ascites & 1 & 0.3 & 1 & 0.2 & 2 & 0.3 & 2 & 0.2 & 6 & 0.2 \\
\hline Thoracic fluid & 1 & 0.3 & 1 & 0.2 & 1 & 0.1 & & & 3 & 0.1 \\
\hline $\begin{array}{l}\text { Bile } \\
\text { Joint fluid }\end{array}$ & 22 & 5.6 & 22 & 4.0 & 20 & 2.6 & 26 & 3.2 & 90 & 3.5 \\
\hline $\begin{array}{l}\text { Joint fluid } \\
\text { Washout liquid }\end{array}$ & 1 & 0.3 & 1 & 0.2 & & & 1 & 0.1 & 3 & 0.1 \\
\hline Skin piece & & & & & & & & & & \\
\hline Others & 6 & 1.5 & 3 & 0.5 & 11 & 1.4 & 5 & 0.6 & 25 & 1.0 \\
\hline Total & 396 & 100.0 & 553 & 100.0 & 776 & 100.0 & 815 & 100.0 & 2,540 & 100.0 \\
\hline
\end{tabular}

\section{Results of Annual Investigations of Drug Sensitivities}

\section{Methods}

In comparing the data of annual investigations of bacterial drug sensitivities, we compared the average values of the M. I. C. of the total isolates studied as we have reported previously ${ }^{5}$. This comparison was made on the assumption that the levels of sensitivities of the isolates to each drugs give a normal distribution curve, but it has been
Table 4. Multiple correlation coefficients for the items shown in Table 1 .

\begin{tabular}{|c|c|c|c|c|c|}
\hline \multicolumn{5}{|c|}{ Items } & \multirow{2}{*}{$\begin{array}{c}\begin{array}{c}\text { Level of } \\
\text { significance }\end{array} \\
\mathrm{P}=0.01\end{array}$} \\
\hline$A$ & $-B$ & $C$ & $\mathrm{D}$ & $\mathrm{E}$ & \\
\hline B & $-\mathrm{A}$ & $\mathrm{C}$ & $\mathrm{D}$ & $E$ & $" \prime$ \\
\hline $\mathrm{C}$ & $-A$ & $B$ & $\mathrm{D}$ & $E$ & "I \\
\hline $\mathrm{D}$ & $-A$ & $\mathrm{~B}$ & $\mathrm{C}$ & $\mathrm{E}$ & "I \\
\hline $\mathrm{E}$ & $-A$ & B & $\mathrm{C}$ & $\mathrm{D}$ & "I \\
\hline \multicolumn{6}{|c|}{$\begin{array}{l}\text { (Remarks) } \\
\text { A : Population } \\
\text { B : Total number of hospitals } \\
\text { C : Number of sampling hospitals } \\
\text { D : Number of } S . \text { aureus strains } \\
\text { E : Number of } E \text {. coli strains }\end{array}$} \\
\hline
\end{tabular}

found that this assumption does not fit all the drugs used. We have, therefore, classified the bacterial isolates into groups of high sensitivity, intermediate sensitivity and low sensitivity according to their M.I.C. values in the present investigation. Annual changes of the bacterial drug sensitivities were compared statistically in terms of the frequencies of these three groups. The bacteria studied were those isolated from various specimens. The results are reported below for each drug.

\section{Staphylococcus aureus}

(1) Penicillin-G

S. aureus cultures of moderate susceptibility to penicillin were isolated less frequently in 1968 than in 1965. The isolates seem to be more commonly either highly susceptible or highly resistant to the antibiotic. A decrease in isolation of cultures placed in the high sensitivity group occurred in 1966 compared with 1965, whereas an increase was observed for isolates in the low sensitivity group. An increase only of cultures in the low sensitivity group was noted between 1966 and 1967. Between 1967 and 1968, isolates in the high sensitivity group 
increased and cultures in the intermediate sensitivity group decreased. Thus a marked increase in numbers of cultures isolated in the low sensitivity group occurred between 1965 and 1968.

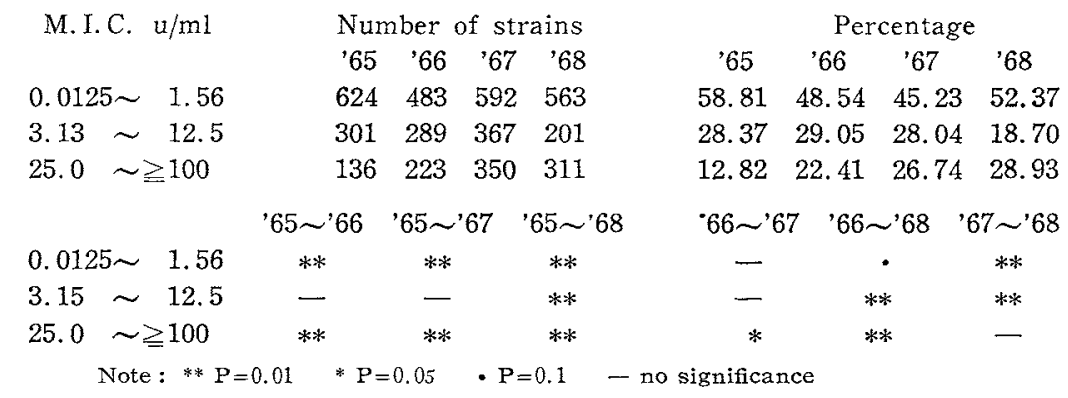

(2) Streptomycin

High-sensitivity group decreased between 1965 and 1966, while a remarkable increase in intermediate-sensitivity group took place in this period.

Almost no change was found in any group between 1966 and 1967, whereas a slight increase in high-sensitivity group and a decrease in intermediate-sensitivity group were observed between 1967 and 1968. As a result, a profound decrease in high-sensitivity group and a marked increase in intermediate-sensitivity group occurred between 1965 and 1968. Highly resistant group with M.I.C. above $100 \mu \mathrm{g} / \mathrm{ml}$ somewhat decreased in this period.

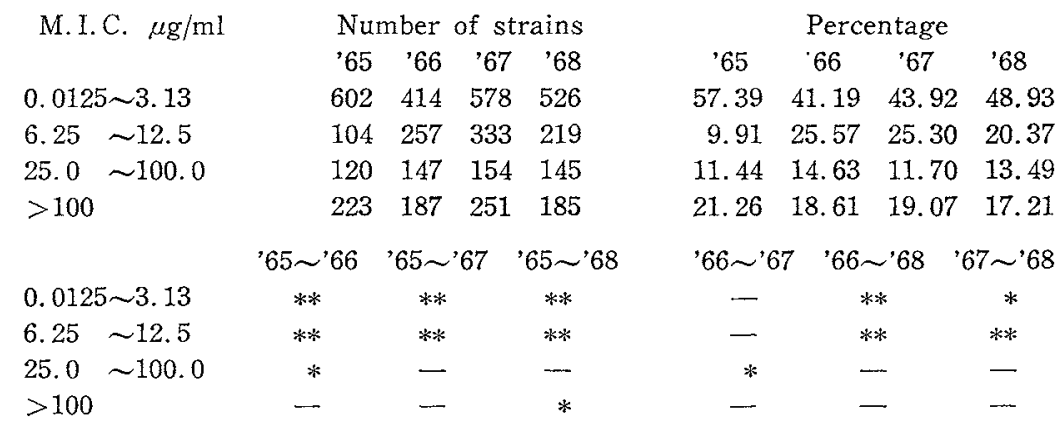

(3) Chloramphenicol

High-sensitivity group showed some increase between 1965 and 1966, but both intermediate-sensitivity group and low-sensitivity group decreased in this period. These was no change in the frequencies of the three groups between 1966 and 1967. Between 1967 and 1968, high-sensitivity group decreased and intermediatesensitivity group increased considerably, whereas low-sensitivity group did not show a change. Both high-sensitivity group and low-sensitivity group decreased between 1965 and 1968, while intermediate-sensitivity group exhibited a remarkable increase in this period.

\begin{tabular}{llrrrr} 
M.I.C. $\mu \mathrm{g} / \mathrm{ml}$ & \multicolumn{4}{c}{ Number of strains } \\
& '65 & '66 & '67 & '68 \\
$0.0125 \sim 3.13$ & 700 & 700 & 904 & 592 \\
$6.25 \sim 12.5$ & 201 & 161 & 235 & 356 \\
$25.0 \sim \geqq 100$ & 163 & 136 & 177 & 127
\end{tabular}

\begin{tabular}{cccc}
\multicolumn{4}{c}{ Percentage } \\
'65 & '66 67 & '68 \\
65.79 & 70.21 & 68.69 & 55.07 \\
18.89 & 16.15 & 17.86 & 33.12 \\
15.32 & 13.64 & 13.45 & 11.81
\end{tabular}




\begin{tabular}{|c|c|c|c|c|c|c|c|}
\hline & & '65 '66 & '65 '67 & '65 '68 & '66 '67 & '66 '68 & $' 67 \sim 68$ \\
\hline $0.0125 \sim$ & -3.13 & * & - & $* *$ & - & $* *$ & $* *$ \\
\hline $6.25 \sim$ & -12.5 & - & - & $* *$ & - & $* *$ & $* *$ \\
\hline $25.0 \sim$ & $-\geqq 100$ & - & - & * & - & - & - \\
\hline
\end{tabular}

(4) Tetracycline

A considerable increase in high-sensitivity group and a decrease in both intermediate-sensitivity group and low-sensitivity group were noted between 1965 and 1966. Almost no change was observed in the frequencies of the three groups between 1967 and 1968. An idential tendency was found also between 1967 and 1968. Thus a marked increase in high-sensitivity group and a decrease in both intermediate-sensitivity group and low-sensitivity group were observed between 1965 and 1968 .

\begin{tabular}{|c|c|c|c|c|c|}
\hline \multirow{2}{*}{\multicolumn{2}{|c|}{ M. I.C. $\mu \mathrm{g} / \mathrm{ml}$}} & \multicolumn{4}{|c|}{ Number of strains } \\
\hline & & '65 & '66 & '67 & 68 \\
\hline $0.0125 \sim$ & $\quad 1.56$ & 529 & 604 & 792 & 651 \\
\hline $3.13 \sim$ & $\sim 12.5$ & 64 & 18 & 11 & 10 \\
\hline \multirow[t]{2}{*}{25.0} & $\longrightarrow 100$ & 466 & 383 & 503 & 414 \\
\hline & & $' 65 \sim ' 66$ & '65 ' & & $65 \sim 68$ \\
\hline $0.0125 \sim$ & 1.56 & $* *$ & ** & & ** \\
\hline $3.13 \sim$ & $\quad 12.5$ & $* *$ & $* *$ & & $* *$ \\
\hline $25.0 \sim \geqq$ & $\geq 100$ & $* * *$ & $* *$ & & $* *$ \\
\hline
\end{tabular}

\begin{tabular}{rrrr}
\multicolumn{5}{c}{ Percentage } \\
'65 & \multicolumn{1}{c}{66} & \multicolumn{1}{c}{67} & \multicolumn{1}{c}{$' 68$} \\
49.95 & 60.10 & 60.64 & 60.56 \\
6.04 & 1.79 & 0.84 & 0.93 \\
44.00 & 38.11 & 38.51 & 38.51 \\
$' 66 \sim ' 67$ & $' 66 \sim ' 68$ & $' 67 \sim ' 68$ \\
- & - & - \\
$*$ & - & - \\
- & - & -
\end{tabular}

(5) Erythromycin

A decrease in high-sensitivity group and an increase in low-sensitivity group occurred between 1965 and 1966. Intermediate-sensitivity group decreased and low-sensitivity group increased between 1966 and 1967. An increase in lowsensitivity group was found between 1967 and 1968 but no change was observed in the other groups in this period. Consequently, a marked decrease in highsensitivity group and a decrease in intermediate-sensitivity group occurred between 1965 and 1968 resulting in a remarkable increase in low-sensitivity group.

\begin{tabular}{|c|c|c|c|c|c|c|c|}
\hline \multirow[t]{2}{*}{ M. I. C. $\mu \mathrm{g} / \mathrm{ml}$} & \multicolumn{3}{|c|}{ Number of strains } & \multicolumn{4}{|c|}{ Percentage } \\
\hline & '65 & '66 '67 & '68 & '65 & '66 & '67 & '68 \\
\hline $0.0125 \sim 1.56$ & 819 & $\begin{array}{ll}726 & 907\end{array}$ & 714 & 76.90 & 72.24 & 69.24 & 466.42 \\
\hline $3.13 \sim 12.5$ & 56 & 52 & 23 & 5.26 & 5.17 & 2.60 & 2.14 \\
\hline $25.0 \sim \geqq 100$ & 190 & $227 \quad 369$ & 338 & 17.84 & 22.59 & 28.17 & 31.44 \\
\hline & ' $65 \sim ' 66$ & '65 '67 & $' 65 \sim ' 68$ & $' 66 \sim ' 6$ & 67 & -68 & $67 \sim 68$ \\
\hline $0.0125 \sim 1.56$ & * & $* *$ & $* *$ & - & & * & - \\
\hline $3.13 \sim 12.5$ & - & $* *$ & $* *$ & $* *$ & & * & - \\
\hline $25.0 \sim \geq 100$ & $* *$ & $* * *$ & $* *$ & $* *$ & & * & - \\
\hline
\end{tabular}

(6) Kanamycin

High-sensitivity group decreased considerably between 1965 and 1966, and intermediate-sensitivity group and low-sensitivity group increased in this period. There was almost no change in any group between 1966 and 1967 and between 1967 and 1968. Consequently, a considerable decrease in high-sensitivity group and a remarkable increase in intermediate-sensitivity group were observed between 1965 and 1968. An increase in intermediate-sensitivity group was also found in this period. 
M.I.C. $\mu \mathrm{g} / \mathrm{ml}$

$0.0125 \sim 1.56$

$3.13 \sim 12.5$

$25.0 \sim \geqq 100$

$0.0125 \sim 1.56$

$3.13 \sim 12.5$

$25.0 \sim \geqq 100$
Number of strains

$\begin{array}{llll}\prime 65 & \prime 66 & \prime 67 & \prime 68\end{array}$

$\begin{array}{lllll}869 & 676 & 670 & 572\end{array}$

$\begin{array}{llll}144 & 244 & 546 & 428\end{array}$

$\begin{array}{llll}36 & 72 & 94 & 74\end{array}$

'65 ' $66 \quad$ '65 ' $67 \quad$ '65 '68

(7) Cephalothin

Only high-sensitivity group was found to this drug and no change was observed from 1965 through 1968.

\begin{tabular}{|c|c|c|c|}
\hline \multirow{2}{*}{ M.I.C. $\mu \mathrm{g} / \mathrm{m} 1$} & \multicolumn{3}{|c|}{ Number of strains } \\
\hline & 65 & '66 '67 & '68 \\
\hline $0.0125 \sim 0.78$ & 543 & 9921294 & 1073 \\
\hline $1.56 \sim 12.5$ & 1 & 9 & 2 \\
\hline $25.0 \sim \geqq 100$ & 0 & 0 & 0 \\
\hline & '65 '66 & $' 65 \sim ' 67$ & '65 ' 6 \\
\hline $.0125 \sim 0.78$ & - & - & - \\
\hline $1.56 \sim 12.5$ & - & - & - \\
\hline $25.0 \sim \geqq 100$ & & & \\
\hline
\end{tabular}

\begin{tabular}{|c|c|c|c|}
\hline \multicolumn{4}{|c|}{ Percentage } \\
\hline 65 & '66 & 67 & '68 \\
\hline 99.82 & 99.60 & 99.31 & 99.81 \\
\hline 0.18 & 0.42 & 0.69 & 0.19 \\
\hline 0.00 & 0.00 & 0.00 & 0.00 \\
\hline ' $66 \sim ' 67$ & $7 \quad 66$ - & ' 68 & $67 \sim 68$ \\
\hline 一 & & & \\
\hline & & & \\
\hline
\end{tabular}

(8) Cephaloridine

Only high-sensitivity group was found also to this drug and no change was observed from 1965 through 1968.

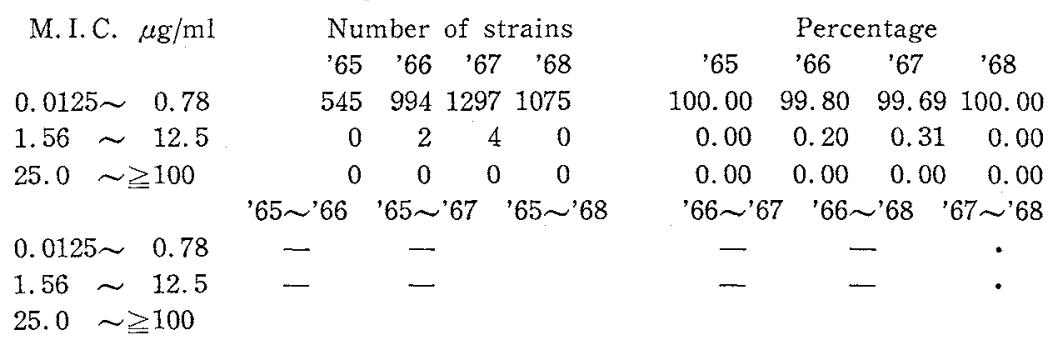

(9) Aminobenzyl-penicillin

No change was found in the frequencies of the three groups between 1967 and 1968.

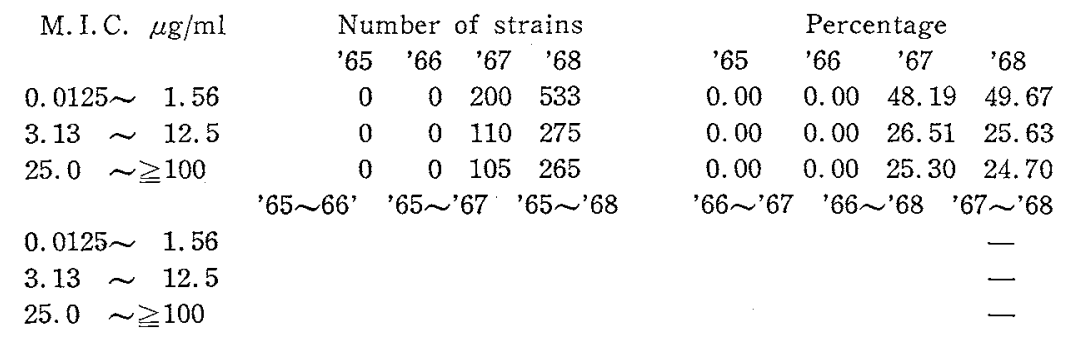

\section{Escherichia coli}

(1) Chloramphenicol

Between 1965 and 1966, high-sensitivity group decreased markedly and intermediate-sensitivity group increased considerably, whereas no change was found in the frequency of low-sensitivity group. A slight decrease was observed in intermediate-sensitivity group between 1966 and 1967. Thus a remarkable 
decrease in high-sensitivity group and a moderate increase in intermediatesensitivity group took place between 1965 and 1968, while no change was found in low-sensitivity group in this period.

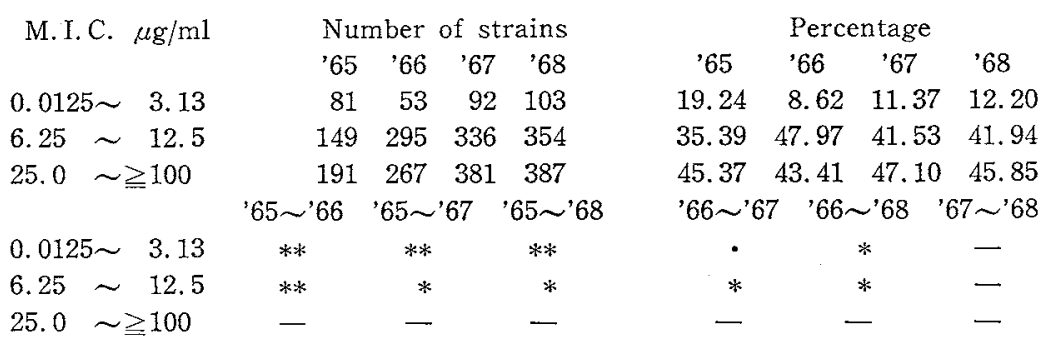

(2) Cephaloridine

A decrease in high-sensitivity group and a considerable increase in intermediate-sensitivity group occurred between 1966 and 1967. A similar tendency was observed also between 1967 and 1968; high-sensitivity group decreased and intermediate-sensitivity group increased. Accordingly, a marked decrease in high-sensitivity group was accompanied by a profound increase in intermediatesensitivity group between 1966 and 1968. There was some increase in lowsensitivity group in this period.

\begin{tabular}{|c|c|c|c|c|c|c|c|c|}
\hline \multirow{2}{*}{\multicolumn{2}{|c|}{ M.I.C. $\mu \mathrm{g} / \mathrm{ml}$}} & \multicolumn{3}{|c|}{ Number of strains } & \multicolumn{4}{|c|}{ Percentage } \\
\hline & & '65 & $' 66$ & '68 & 65 & '66 & 67 & '68 \\
\hline $0.0125 \sim$ & $\sim \quad 1.56$ & 12 & $360 \quad 403$ & 370 & 80.00 & 59.41 & 50.12 & 43.84 \\
\hline $3.13 \sim$ & $\sim 12.5$ & 3 & $228 \quad 375$ & 433 & 20.00 & 37.62 & 46.64 & 51.30 \\
\hline \multirow[t]{2}{*}{25.0} & $\sim \geqq 100$ & 0 & 18 & 41 & 0.00 & 2.97 & 3.23 & 4.86 \\
\hline & & $65 \sim 66$ & $' 65 \sim 67$ & $' 65 \sim 68$ & $' 66 \sim ' 67$ & '66. & $L^{\prime} 68$ & $67 \sim ' 68$ \\
\hline $0.0125 \sim$ & $\sim 1.56$ & - & * & $* *$ & $* *$ & & $\therefore$ & $*$ \\
\hline $3.13 \sim$ & $\sim \quad 12.5$ & - & * & * & $* *$ & & $*$ & - \\
\hline $5.0 \sim$ & $\sim \geqq 100$ & 一 & - & 一 & - & & - & - \\
\hline
\end{tabular}

(3) Cephalothin

There were some increase in high-sensitivity group, a great increase in intermediate-sensitivity group and a marked decrease in low-sensitivity group between 1965 and 1966. Intermediate-sensitivity group decreased and low-sensitivity group increased between 1966 and 1967. A slight increase in high-sensitivity group and a slight decrease in low-sensitivity group were found between 1967 and 1968. Consequently, a tendency of increase in high-sensitivity group and decrease in low-sensitivity group was observed between 1965 and 1968.

\begin{tabular}{|c|c|c|c|c|c|c|c|c|}
\hline \multirow{2}{*}{\multicolumn{2}{|c|}{ M.I.C. $\mu \mathrm{g} / \mathrm{ml}$}} & \multicolumn{3}{|c|}{ Number of strains } & \multicolumn{4}{|c|}{ Percentage } \\
\hline & & '65 & '66 '67 & '68 & 65 & ' 66 & 67 & '68 \\
\hline 0.0125 & $\sim \quad 1.56$ & 1 & 10 & 23 & 0.32 & 1.66 & 1.36 & 2.73 \\
\hline $3.13 \sim$ & $\sim 12.5$ & 249 & $515 \quad 636$ & 684 & 80.06 & 85.69 & 68.81 & 81.04 \\
\hline $25.0 \sim$ & $\sim \geqq 100$ & 61 & $76 \quad 160$ & 137 & 19.61 & 12.65 & 19.83 & 16.23 \\
\hline & & '65 '66 & ' $65 \sim ' 67$ & ' $65 \sim 68$ & ' $66 \sim 6$ ' & $7 \quad 66$ - & - 68 , & ' $67 \sim 68$ \\
\hline $0.0125 \sim$ & $\sim 1.56$ & - & - & $* *$ & 一 & - & - & - \\
\hline $3.13 \sim$ & $\sim 12.5$ & $*$ & - & 一 & $* *$ & & * & - \\
\hline 25.0 & $\sim \geqq 100$ & $* *$ & 一 & - & $* *$ & & - & - \\
\hline
\end{tabular}

(4) Kanamycin

Intermediate-sensitivity group decreased between 1965 and 1966, and highsentitivity group and low-sensitivity group increased in this period. 
High-sensitivity group further increased between 1966 and 1967. High-sensitivity group decreased between 1967 and 1968 and low-sensitivity group showed a tendency of increase in this period. Thus a decrease in intermediate-sensitivity group and an increase in both high-sensitivity group and low-sensitivity group were observed between 1966 and 1968.

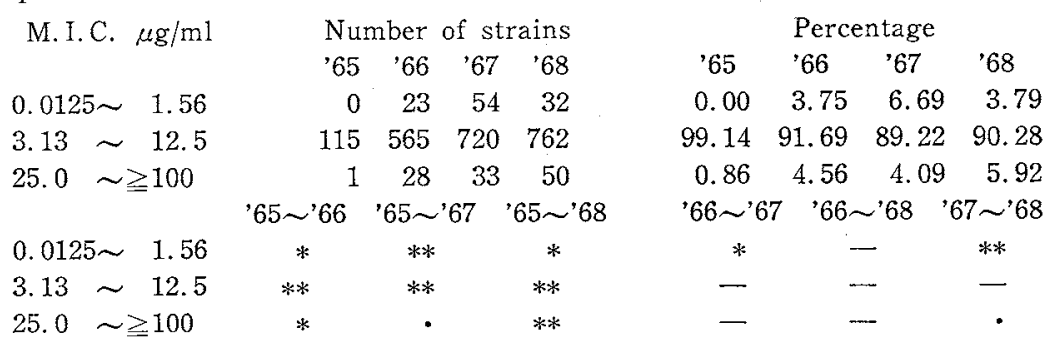

(5) Streptomycin

A slight decrease in high-sensitivity group and some increase in intermediatesensitivity group were found between 1965 and 1966. Both high-sensitivity group and intermediate-sensitivity group decreased and low-sensitivity group increased between 1966 and 1967. A decrease in intermediate-sensitivity group and an increase in high-sensitivity group took place between 1967 and 1968. The overall tendency between 1965 and 1968 was that almost no change occurred in this period.

\begin{tabular}{|c|c|c|c|c|c|c|c|c|}
\hline \multirow[t]{2}{*}{ M.I.C. $\mu \mathrm{g} / \mathrm{ml}$} & \multicolumn{4}{|c|}{ Number of strains } & \multicolumn{4}{|c|}{ Percentage } \\
\hline & '65 & '66 & 67 & 68 & '65 & '66 & ' 67 & 68 \\
\hline $0.0125 \sim 3.13$ & 95 & 137 & 139 & 231 & 27.94 & 22.91 & 17.18 & 27.37 \\
\hline $6.25 \sim 12.5$ & 57 & 132 & 165 & 115 & 16.76 & 22.07 & 20.40 & 13.63 \\
\hline $25.0 \sim 100$ & 107 & 161 & 286 & 280 & 31.47 & 26.92 & 35.35 & 33.18 \\
\hline \multirow[t]{2}{*}{$>100$} & 81 & 168 & 219 & 218 & 23.82 & 28.09 & 27.07 & 25.83 \\
\hline & '65 '66 & $65 \sim$ & & $65 \sim ' 68$ & $' 66 \sim 67$ & 7. '66 & $\sim^{\prime} 68$ & $67 \sim 68$ \\
\hline $0.0125 \sim 3.13$ & - & $* *$ & & - & $* *$ & & - & $* *$ \\
\hline $6.25 \sim 12.5$ & - & - & & - & - & *: & & $* *$ \\
\hline $25.0 \sim 100$ & 一 & - & & - & $* *$ & & * & 一 \\
\hline$>100$ & 一 & - & & - & - & - & & - \\
\hline
\end{tabular}

(6) Tetracycline

High-sensitivity group increased considerably and both intermediate-sensitivity group and low-sensitivity group decreased between 1965 and 1966. An increase in low-sensitivity group and a decrease in intermediate-sensitivity group occurred between 1966 and 1967. Low-sensitivity group decreased and intermediate-sensitivity group increased between 1967 and 1968. The overall change between 1965 and 1968 was a marked decrease in high-sensitivity group, but there was no change in low-sensitivity group.

\begin{tabular}{|c|c|c|c|c|c|c|c|}
\hline \multirow[t]{2}{*}{ M. I. C. $\mu \mathrm{g} / \mathrm{m} 1$} & \multicolumn{3}{|c|}{ Number of strains } & \multicolumn{4}{|c|}{ Percentage } \\
\hline & '65 & '66 '67 & '68 & '65 & '66 & ' 67 & 68 \\
\hline $0.0125 \sim 1.56$ & 19 & $129 \quad 173$ & 172 & 4.66 & 20.98 & 21.54 & J. \\
\hline $3.13 \sim 12.5$ & 168 & $158 \quad 135$ & 200 & 41.18 & 25.69 & 16.81 & 23.70 \\
\hline $25.0 \sim \geqq 100$ & 221 & $328 \quad 495$ & 472 & 54.17 & 53.33 & 61.64 & 55.9 \\
\hline & '65 '66 & '65 ' 67 & $65 \sim ' 68$ & $' 66 \sim ' 67$ & 7 '66 - & & $67 \sim 68$ \\
\hline $0.0125 \sim$ & $* *$ & $* *$ & $* *$ & - & - & & - \\
\hline $3.12 \sim 12.5$ & $* *$ & $* *$ & $* *$ & *** & - & & ** \\
\hline $25.0 \sim \geqq 100$ & - & * & - & $* *$ & - & & $*$ \\
\hline
\end{tabular}


(7) Aminobenzyl penicillin

A considerable decrease in intermediate-sensitivity group accompanied by an increase in high-sensitivity group and low-sensitivity group was observed between 1967 and 1968 .

\begin{tabular}{|c|c|c|c|c|c|c|c|c|c|}
\hline \multirow{2}{*}{\multicolumn{2}{|c|}{ M.I.C. $\mu \mathrm{g} / \mathrm{ml}$}} & \multicolumn{4}{|c|}{ Number of strains } & \multicolumn{4}{|c|}{ Percentage } \\
\hline & & ' 65 & $' 66$ & 67 & ' 68 & 65 & '66 & 67 & '68 \\
\hline 0.0125 & $\sim 3.13$ & 0 & 0 & 80 & 599 & 0.00 & 0.00 & 54.7 & 972.00 \\
\hline $6.25 \sim$ & $\sim 12.5$ & 0 & 0 & 50 & 111 & 0.00 & 0.00 & 34.2 & $5 \quad 13.34$ \\
\hline \multirow[t]{2}{*}{25.0} & $\sim \geqq 100$ & 0 & 0 & 16 & 122 & 0.00 & 0.00 & 10.5 & $6 \quad 14.66$ \\
\hline & & '65〜'66 & '65 ' & & $65 \sim ' 68$ & '66 '67 & '66 & '68 & $' 67 \sim ' 68$ \\
\hline $0.0125 \sim$ & $\sim 3.13$ & & & & & & & & ** \\
\hline 6.25 & $\sim 12.5$ & & & & & & & & $* *$ \\
\hline 25.0 & $\sim \geqq 100$ & & & & & & & & 一 \\
\hline
\end{tabular}

\section{Discussion and Conclusion}

As we have described above, we have been able to learn the changes of bacterial sensitivities to each drug more accurately through comparing the annual changes of the high-sensitivity group, intermediate-sensitivity group and low-sensitivity group, which were classified according to the M. I. C. values of the bacterial isolates, than by our previous method of comparison of the annual averages of the M. I. C. values.

(1) In S. aureus, both high-sensitivity group and intermediate-sensitivity group decreased and low-sensitivity group increased against penicillin-G, erythromycin and kanamycin. A decrease in high-sensitivity group and a considerable increase in intermediate-sensitivity group accompanied by either a decrease or no change in lowsensitivity group were found in $S$. aureus against chloramphenicol and streptomycin. High-sensitivity group increased and both intermediate-sensitivity group and lowsensitivity group decreased against tetracycline.

(2) In E. coli, both high-sensitivity group and low-sensitivity group increased against aminobenzyl-penicillin and kanamycin. Only high-sensitivity group increased against cephalothin. High-sensitivity group decreased and both intermediate-sensitivity group and low-sensitivity group increased against cephaloridine. A marked decrease in high-sensitivity group and an increase in intermediate-sensitivity group without a

Table 5 .

\begin{tabular}{|c|c|c|c|c|c|c|c|c|c|c|}
\hline & \multirow{2}{*}{ Group } & \multicolumn{9}{|c|}{ Drug } \\
\hline & & $P C-G$ & $\mathrm{AB}-\mathrm{PC} *$ & SM & $\mathrm{CP}$ & $\mathrm{TC}$ & KM & $\mathrm{EM}$ & CET & $\mathrm{CER} * *$ \\
\hline \multirow{3}{*}{ S. aureus } & High-sensitivity group & $\downarrow$ & $\rightarrow$ & $\downarrow$ & $\downarrow$ & $\hat{\imath}$ & $\downarrow$ & $\downarrow$ & $\rightarrow$ & $\rightarrow$ \\
\hline & $\begin{array}{l}\text { Intermediate- } \\
\text { sensitivity group }\end{array}$ & $\downarrow$ & $\rightarrow$ & $\uparrow$ & $\uparrow$ & $\downarrow$ & $\uparrow$ & $\downarrow$ & $\rightarrow$ & $\rightarrow$ \\
\hline & Low-sensitivity group & $\rightarrow$ & $\rightarrow$ & $\rightarrow$ & 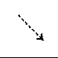 & $\downarrow$ & $\uparrow$ & $\uparrow$ & $\rightarrow$ & $\rightarrow$ \\
\hline \multirow{3}{*}{ E. coli } & High-sensitivity group & & $\uparrow$ & $\rightarrow$ & $\downarrow$ & $\uparrow$ & $\hat{\imath}$ & & $\uparrow$ & $\downarrow$ \\
\hline & $\begin{array}{l}\text { Intermediate- } \\
\text { sensitivity group }\end{array}$ & & $\downarrow$ & $\rightarrow$ & $\hat{\imath}$ & $\downarrow$ & $\downarrow$ & & $\rightarrow$ & $\uparrow$ \\
\hline & Low-sensitivity group & & $\uparrow$ & $\rightarrow$ & $\rightarrow$ & $\rightarrow$ & $\uparrow$ & & $\rightarrow$ & $\uparrow$ \\
\hline
\end{tabular}

PC-G : Penicillin. AB-PC: Aminobenzyl-penicillin. SM : Streptomycin. CP: Chloramphenicol.

TC: Tetracycline. KM: Kanamycin. EM : Erythromycin. CET:Cephalothin. CER : Cephaloridine.

$\uparrow$ Increase $\downarrow$ Decrease $\rightarrow$ No change $\backslash$ Slight decrease

* 1967, $1968 \quad * * 1966,1967,1968$ 
change in low-sensitivity group were found against chloramphenicol. A tendency opposite to that against chloramphenicol was found against tetracycline. No change was observed in any of the three groups against streptomycin.

These data can be summarized as in Table 5 .

We believe that it has become possible to perform more accurate comparative studies of the annual changes of the bacterial drug sensitivities with the method described in the present paper than with our previous method.

\section{Acknowledgement}

We express our sincere gratitude to those who have kindly supplied us with the strains for this study and hope for their continuous cooperation. We also thank Porf. N. KosAKAI of Juntendo University School of Medicine for his guidance in testing methods, Dr. T. Iwaki and Dr. H. Nishimura of Shionogi \& Co., Ltd. for their help and Miss. Krmura for her cooperation.

\section{References}

1) Research Committee of the Drug Resistance cooperated with National Hospitals : Distribution of resistant Staphylococci (in Japanese). Mod. Med. 15 (Suppl.) : 2 8, 1960

Research Committee of the Drug Resistance cooperated with National Hospitals : Distribution of resistant Staphylococci (in Japanese). Mod. Med. $16: 2997 \sim 3004,1961$

2) Research Committee on the Drug Resistance: Drug resistance in Staphylococcus aureus. I. Chemotherapy $14: 1 \sim 8,1966$

Research Committee on the Drug Resistance: Drug resistance in Staphylococcus aureus. II. Chemotherapy $14: 392 \sim 396,1966$

Research Committee on the Drug Resistance: Drug resistance in Staphylococcus aureus. III. Chemotherapy $15: 195 \sim 197,1967$

Research Committee on the Drug Resistance: Drug resistance in Staphylococcus aureus. IV. Chemotherapy $16: 843 \sim 846,1968$

3) Hashimoto, H. \& S. Mitsuhashi: Studies on drug-resistances of Staphylococci (in Japanese). J. Antibiotics, Ser. B $17: 129 \sim 132,1964$

SEIGA, K. \& K. Y YMAKI : Antibiotic-resistances of pathogenic staphylococci isolates in 1965 (in Japanese). Chemotherapy $14: 584 \sim 585,1966$

4) Bunger, P.; W. Diller, J. Fuhr \& E. Krǘger-Thimer : Vergleichende Untersuchungen an neueren Sulfanilamiden. Arzneimittel Forsch. $11: 253 \sim 267,1961$

5) Otaya, H. \& E. Inoue: Report on the drug resistance of Staphylococci and Escherichia coli against antibiotics and sulphonamide. I. (in Japanese). Mod. Med. $22: 2545 \sim 2568,1967$

OTAYA, H.; E. InOUe \& E. MACHIHARA : Report on the drug resistance against antibiotics. II. The statistical analysis of sensitivity (in Japanese). General meeting of the west-Japan branch Society of Chemotherapy pp. 11 12, Dec. 22, 1967 (Hiroshima)

OTAYA, H.; S. Окамото \& E. Inoue: Report on the drug resistance of Staphylococci and Escherichia coli against antibiotics (in Japanese). General meeting of the Japan Society of Chemotherapy p. 37, Apr. 24 26, 1969 (Osaka) 